Anthropos: Jurnal Antropologi Sosial dan Budaya (Journal of Social and Cultural Anthropology)

5 (2) (2020): 183-195, DOI: https://doi.org/10.24114/antro.v5i2.14922

Anthropos: Jurnal Antropologi Sosial dan Budaya

(Journal of Social and Cultural Anthropology)

Available online http://jurnal.unimed.ac.id/2012/index.php/anthropos

\title{
Kekuatan Simbolik Beras dalam Ritus Kehidupan Masyarakat Batak Toba
}

\section{The Symbolic Power of Rice in the Rites of the Toba Batak People's Life}

\author{
Resmi Hutasoit*, Izak M. Lattu \& Ebenhaizer I Nuban Timo \\ Jurusan Sosiologi Agama, Fakultas Teologi, Universitas Kristen Satya Wacana, Indonesia
}

Diterima: 25-10-2019; Disetujui: 24-11-2019; Dipublish: 30-01-2020

\begin{abstract}
Abstrak
Artikel ini bertujuan untuk menganalisis latar belakang atau sejarah beras digunakan sebagai simbol penguat roh dalam ritus tahapan kehidupan di tanah Batak yang dilakukan dalam adat pernikahan, lepas dari marabahaya, naik jabatan, memasuki rumah baru juga ketika anak dibaptis. Metode yang digunakan adalah metode kualitatif dengan teknik wawancara, observasi dan studi pustaka. Hasil penelitian menemukan bahwa beras memiliki nilai sakral bagi masyarakat Batak. Beras pada umumnya dimiliki oleh orang kaya dan miskin sehingga ada kesetaraan sosial sehingga menggunakan beras sebagai simbol penguat roh. Beras memberikan kebutuhan jasmani untuk kesehatan. Kesehatan jasmani manusia sangat berpengaruh terhadap roh manusia. Saat pemberian beras dalam acara tertentu ada unsur keselamatan, ketika beras tersebut di ditaruh diatas kepala dan dihamburkan. Mereka menggunakan beras sebagai simbol dalam ritus tertentu secara turun-temurun dari nenek moyangnya. Beras bagi Batak memiliki nilai sejarah yang sangat tinggi yaitu dari proses penanaman padi hingga menjadi beras. Tulisan ini memberikan sumbangsih kepada tokoh adat serta pemuda agar tetap melestarikandan memahami tradisi dari nenek moyang. Kata Kunci: Simbol, Ritus, Beras.
\end{abstract}

\begin{abstract}
This article aims to analyze the background or history of rice used as a symbol of spirit strengthening in the rites of life stages in the Batak land which are carried out in the adat of marriage, free from distress, promotion, entering a new home also when the child is baptized. The method used is a qualitative method with interview, observation and literature study techniques. The results found that rice has a sacred value for the Batak people. Rice is generally owned by the rich and poor so that there is social equality so that using rice as a symbol of spirit strengthening. Rice provides physical needs for health. Human physical health is very influential on the human spirit. When giving rice in certain events there is an element of safety, when the rice is placed over the head and scattered. They use rice as a symbol in certain rites from generation to generation from their ancestors. Rice for the Batak has a very high historical value from the process of planting rice to rice. This paper contributes to traditional leaders and young people to preserve and understand the traditions of their ancestors.
\end{abstract}

Keywords: Symbols, Rites, Rice.

How to Cite: Hutasoit, R. , Lattu, I.M, \& Timo, E.I.N (2020). Kekuatan Simbolik Beras dalam Ritus Kehidupan Masyarakat Batak Toba. Anthropos: Jurnal Antropologi Sosial dan Budaya Oournal of Social and Cultural Anthropology) 5(2): 183-195.

${ }^{*}$ Corresponding author:

ISSN 2460-4585 (Print)

E-mail: resmihutasoit123@gmail.com

ISSN 2460-4593 (Online) 


\section{PENDAHULUAN}

Dalam Kamus Besar Bahasa Indonesia (KBBI) beras adalah padi yang telah terkelupas kulitnya (yang menjadi nasi setelah ditanak). Bagi banyak orang beras hanyalah sebuah benda kecil dan keras dan akan lunak setelah dimasak. Beras merupakan makanan pokok di Asia dan Amerika Latin termasuk Indonesia. Beras salah satu makanan yang tinggi kandungan karbohidrat bagi manusia dan juga bagi hewan. Sejarah padi di Indonesia diduga berasal dari India atau Indocina dan masuk ke Indonesia di bawa oleh nenek moyang yang migrasi dari daratan Asia sekitar 1500 SM. Beras dalam tradisi agraris seperti Indonesia merupakan tanaman unggulan walaupun sebagian daerah lain masih mengandalkan tanaman yang lain.

Di seluruh belahan Indonesia, padi memiliki sejarah yang berbeda-beda serta fungsi yang berbeda. Sameng, Munawaroh \& Suprapto (2003), dalam penelitiannya tentang ilmu kecantikan mengatakan bahwa kandungan zat orizonal yang terdapat di dalam beras bisa untuk merawat kulit seperti mengatasi masalah jerawat yang disebabkan oleh infeksi bakteri Staphylococcus epidermidis. Dalam penelitannya bertujuan untuk mengetahui daya hambat sari beras terhadap bakteri Staphylococcus epidermidis setelah diformulasikan dalam sediaan sabun beras padat.

Misrita dalam tulisannya mengenai tradisi tandak Tawur behas 'beras' masyarakat Dayak Ngaju Kalimantan Tengah menggunakan beras sebagai salah satu bagian atau babak dari acara manawar 'menabur' dalam acara awal dari sesuatu gawi 'kerja/upacara/pesta' yang menyangkut kematian 'gawi matei' maupun kehidupan 'gawi belum. Tawur adalah sebuah aktivitas sakral yang dilakukan oleh pemimpin adat suku Dayak. Tawurmerupakan sebuah tindak tutur ritual untuk menyampaikan semacam permohonan atau doa kepada Sangiang sebagai Wujud Tertinggi dengan medium beras 'behas' sebagai perantara hubungan antara manusia dengan wujud tertinggi tersebut. Dalam budaya Dayak Ngaju behas 'beras' diyakini sebagai perlambang dewa yang memiliki keutamaankeutamaan, ia dapat sampai, bertemu, dan pada akhirnya dapat menyampaikan permohonan manusia kepada Wujud Tertinggi.

Dari dua hasil penelitian di atas jelas bahwa beras digunakan untuk kecantikan atau kosmetik dan sebagai alat ritual adat tertentu. Beras bagi kecantikan memiliki daya hambat terhadap Staphylococcus epidermidis yaitu sejenis bakteri yang menimbulkan jerawat pada 
manusia. Sari beras diformulasikan dalam sediaan sabun beras padat untuk digunakan. Bagi masyarakat Dayak Ngaju Kalimantan Tengah menggunakan beras sebagai salah satu bagian dari acara menabur dalam acara awal dari sesuatu upacara yang menyangkut kematian maupun kehidupan. Mereka biasanya disebut umat Hindu Kaharingan yaitu sebuah aliran kepercayaan Kalimantan Tengah yang menggunakan beras dalam kehidupan ibadah sehari-hari. Beras dipandang bukan hanya sebagai bahan makanan, namun beras digunakan sebagai sarana penting dalam kehidupan beribadah kepada Sang Pencipta.

Tulisan ini mengkaji tentang ritual Boras Si Pir Ni Tondi atau jika diterjemahkan dalam bahasa Indonesia yaitu beras si penguat roh. Di mana tradisi ini telah dilakukan secara turun-temurun dari nenek moyang dan sampai saat ini masih tetap dilakukan. Banyak peneliti telah menjelaskan tentang ritus dan budaya Batak. Sihotang (2016) yang meneliti terlebih dahulu mengenai Falsafah Boras Sipir Ni Tondi Dalam Upacara Pesta Adat Perkawinan Batak Toba Di Desa Pusuk I Kecamatan Parlilitan Kabupaten Humbang Hasundutan. Dalam penelitian tersebut kurang menggali mengapa menggunakan beras sebagai simbol. Lenny Lusia Simatupang dkk
$(2015)$ penelitian yang berjudul "Pengalaman Pasien Suku Batak Toba Dengan Gagal Ginjal Kronis Dalam Menjalani Hemodialisa". Dalam penelitian beliau penulis melihat bahwa adat Batak digunakan dalam pastoral atau sebagai penguatan bagi yang mengalami sakit. Gaol (2007) penelitiannya yang berjudul "Tanda-tanda Dalam Perkawinan Batak Toba (Tinjauan Semiotika)". Dalam tulisan beliau, tradisi pemberian Boras Si Pir Ni Tondi selalu dilakukan, namun tidak menganalisa mengapa menggunakan beras. Dari ketiga hasil penelitian tersebut kita perhatikan kurang mengekslorasi sejarah dan latar belakang mengapa menggunakan beras dalam tradisi.

Berkaitan dengan hal tersebut dalam penulisan ini, penulis ingin menggali kegunaan beras khususnya bagi suku Batak Toba mempunyai paradigma tersendiri mengenai padi atau beras. Fungsi beras dalam kehidupan orang Batak Toba bukan sekedar makanan pokok, begitu juga dengan umat Hindu Kaharingan Kalimantan Tengah. Lebih dari itu beras memiliki fungsi simbolik penting dalam budaya Batak. Beras memiliki arti penting dalam budaya Batak tentu berakar pada fakta sawah sebagai inti budaya etnik ini. Sejak komunitas pertama terbentuk, orang Batak diketahui sudah menjadi komunitas lembah bersawah. 
Masyarakat Batak menggunakan beras sebagai simbol penguat roh atau jiwa tentu memiliki alasan. Tradisi Boras Si Pir Ni Tondi telah di lakukan dari dahulu oleh neneng moyang (Simatupang, 2008). Tanggal, bulan dan tahun tidak dapat kita pastikan kapan tradisi ini dilakukan oleh nenek moyang masyarakat Batak. Tradisi Boras Si Pir Ni Tondi ini selalu dilakukan saat adat pernikahan, bagi anak yang baru dibabtis, ketika ada yang naik jabatan, lepas dari mara bahaya, dan memasuki rumah baru. Semuanya bertujuan untuk meneguhkan roh manusia, supaya tetap teguh dan kuat. Adat Batak Toba seperti pernikahan tanpa tradisi Boras Si Pir Ni Tondi kurang baik. Pemberian Boras Si Pir Ni Tondi biasanya di letakkan di atas kepala dan saat memasuki rumah baru beras akan di hamburkan keseluruh sudut rumah dengan tujuan agar penghuni rumah dalam keadaan sehat dan kuat rohnya sepanjang mempati rumah tersebut.

Berkaitan dengan hal tersebut, tradisi Boras Si Pir Ni Tondi selalu dilakukan dalam adat tertentu. Pada upacara Sipaha Sada dan Sipaha Lima yang dilakukan oleh Masyarakat Parmalim (Ugamo Malim), utamanya di Hutatinggi Laguboti, Toba Samosir, beras juga menjadi pelan (sesaji) dalam rangkaian upacara tersebut (Suharyanto (2012, 2016,
2019), (2016), Wiflihani \& Suharyanto, (2011).

Saat ini banyak pemuda ataupun kalangan orangtua kurang memahami, mengapa beras digunakan sebagai simbol penguat roh manusia. Pemuda mengetahui dan mengalami tradisi Boras Si Pir Ni Tondi namun tidak mengetahui mengapa harus menggunakan beras dan bukan benda keras lainnya. Penulis sebagai anak Batak Toba keturunan Batak kurang mengerti mengapa harus menggunakan beras. Bagaimana hubungan masyarakat Batak Toba dengan beras sehingga menggunakan beras sebagai simbol. Sehingga dalam tulisan penulis ingin mengkaji lebih dalam mengenai kekuatan simbol beras dalam ritus kehidupan masyarakat Batak Toba.

\section{METODE PENELITIAN}

Secara umum, metode penelitian merupakan suatu kegiatan ilmiah yang dilakukan untuk memperoleh data yang valid dengan tujuan dan kegunaan tertentu (Sugiyono. 2013). Agar tercapainya tujuan penulisan tugas akhir ini maka metode penelitian yang dipakai metode deskriptif analisis, dimana metode penelitian deskriptif adalah metode yang meneliti suatu kelompok manusia, suatu objek, suatu keadaan, suatu pemikiran atau suatu peristiwa pada masa sekarang (Nazir. 1988). Jenis penelitian yang dipakai adalah 
kualitatif. Dengan tujuan untuk menampilkan data bukan dalam bentuk hitungan angka, melainkan dalam bentuk kalimat (Moleong. 1989)

Metode yang digunakan penulis dalam tulisan ini adalah metode penelitian kualitatif. Kajian terhadap pertanyaan yang tercantum dalam penelitian ini dilaksanakan dengan melakukan penelitian mendalam terhadap pemahaman suku Batak Toba mengenai sejarah beras atau padi sehingga digunakan sebagai simbol penguat roh. Data-data dikumpulkan melalui metode focus grup discussion, wawancara mendalam dan penyelidikan literatur yang berhubungan dengan pokok-pokok tersebut. Dalam pelaksanaan wawancara dipakai instrumen pengumpul data berupa daftar pertanyaan sebagai pedoman wawancara bagi para informan yakni tokoh adat, tokoh masyarakat dan juga orangtua. Setelah melakukan penelitian, penulis akan menganalis data yang diperoleh dari hasil wawancara dan catatan lapangan secara sistematis agar mudah dipahami oleh para pembaca. Dengan demikian artikel ini memberikan kesimpulan bahwa sejarah dan mitos padi bagi orang Batak memiliki kekuatan simbol untuk menguatkan roh atau jiwa yang seharusnya dilestarikan.
HASIL DAN PEMBAHASAN

\section{Latar Belakang Beras sebagai Simbol Penguat Roh (Tondi)}

Latar belakang beras sebagai simbol penguat roh yaitu tanaman padi merupakan tanaman budidaya yang sangat penting bagi umat manusia karena lebih dari setengah penduduk dunia tergantung pada tanaman ini sebagai sumber bahan pangan. Hampir seluruh penduduk Indonesia memenuhi kebutuhan bahan pangannya dari tanaman padi. Dengan demikian, tanaman padi merupakan tanaman yang mempunyai nilai spiritual, budaya, ekonomi dan politik yang penting bagi bangsa Indonesia karena memengaruhi hajat hidup orang banyak. Kandungan karbohidrat yang tinggi yang terdapat dalam beras menjadikan tanaman ini tetap dilestarikan. Selain untuk kebutuhan jasmani padi digunakan dalam alat kecantikan. Sari yang terdapat dalam beras diformulasikan dapat membunuh bakteri yang menyebabkan jerawat. Tidak jarang kaum ibu menggunakan tepung beras sebagai masker wajah untuk melindungi wajah dari sengatan terik matahari. Dalam pendahuluan telah dijelaskan bahwa beras juga digunakan untuk alat ritual ibadah.

Selain menjadi makanan pokok, beras memiliki daya yang di percaya oleh berbagai kalangan penduduk Indonesia. 
Seperti halnya bagi masyarakat Jawa padi ataupun beras dimanfaatkan untuk menangkap penampakan gaib yang samar. Dalam keberadaan benda pusaka saat akan mencari tuannya, maka ia akan memancarkan cahaya. Jika cahaya ini menghilang, maka dapat dilakukan dengan menggunakan beras. Misalnya suatu kejadian saat penampakan sinar dari bambu pethuk, maka orang yang melihatnya mendekati secara perlahan dan akan mengambilnya, tetapi cahaya tersebut redup dan hilang. Karena telah membawa beras yang sudah dicuci, lalu beras tersebut disebarkan pada daerah yang tadinya memunculkan cahaya. Dari beras yang dihamburkan, cahaya keluar lagi dari bambu pethuk dan melihatnya, kemudian mengambilnya kembali (Anan, 2015).

Selain makanan pokok beras digunakan dalam adat istiadat masyarakat Batak Toba yang dinamakan dengan Boras Si Pir Ni Tondi. Secara harafiah Boras Si Pir $\mathrm{Ni}$ Tondi berarti "beras penguat roh" (boras = beras; pir = keras, kuat; si pir $n i=$ yang menguatkan; Tondi $=$ roh, jiwa). Secara simbolik, boras si pir ni Tondi bermakna "menguatkan jiwa atau ruh". Makna simbolik beras menunjuk pada doa pengharapan akan kebaikan atau karunia maka pemberian Boras Si Pir Ni Tondi tidak boleh sembarangan. Boras Si
Pir Ni Tondi biasanya diberikan oleh pihak yang menyandang status sosial atau adat yang lebih tinggi. Boras Si Pir $\mathrm{Ni}$ Tondi diberikan oleh hula-hula (pemberi isteri) kepada boru-nya (penerima isteri). Sebab dalam struktur sosial asli orang Batak, yaitu Dalihan $\mathrm{Na}$ Tolu (Tiga Batu Tungku: hula-hula, dongan tubu, boru), status hula-hula ditempatkan sebagai Debata Na Tarida, Dewata yang Terlihat. Dengan kata lain, sebagai "wakil dewata". Dalam Upacara kematian (Saur Matua) bagi masyarakat Batak, pihak hula-hula akan memberikan beras (boras si pir ni Tondi) kepada anak dari yang meninggal.

Bapak Halomoan Sagala adalah Raja Adat (Raja Bius) di Kecamatan Sianjur Mulamula sebagai informan dalam penelitian ini. Beliau mengatakan latar belakang beras digunakan sebagai simbol penguat roh adalah karena padi dari dahulu susah ditanam. Mulai dari pembibitan sampai memanen membutuhkan kesabaran dan tenaga untuk menunggu hingga bisa menjadi beras dan di masak. Beliau juga mengatakan bahwa beras dimiliki oleh orang miskin dan kaya. Boleh dikatakan bahwa ada kesetaraan sosial didalamya. Seandainya menggunakan emas, mungkin semua ornag tidak memilikinya dan hanya orang kayalah yang mampu melakukannya. 
Alasan selanjutnya adalah beras dapat di makan setelah dimasak. Jiwa orang Batak dahulu tidak akan tenang jika makan nasi (molo dang iddahan dang butong), artinya kalau belum makan nasi belum kenyang walaupun sudah makan makanan yang lain. Tanpa makan nasi perut tidak akan kenyang secara sempurna.

Berkaitan dengan hal tersebut dalam memasuki rumah baru beras biasanya akan dihamburkan ke seluruh sudut rumah dan akan mengenai orang yang duduk disana. Beras yang tadinya dihamburkan itu akan mengenai orang dan orang yang terkena beras itu tidak akan tersakiti. Ini adalah alasan menurut beliau mengapa beras digunakan sebagai simbol penguat roh. Adanya kesetraan sosial, menjadi kebutuhan jasmani dan tidak melukai orang hal ini menjadi alasan mengapa beras digunakan sebagai simbol penguat roh menurut beliau.

Pendeta, Tokoh adat, orang yang sudah dituakan, orangtua dan lain sebagainya yang penulis telah wawancarai mengenai mengapa beras digunakan sebagai simbol penguat roh secara umum mereka berpendapat bahwa beras itu keras (pir) artinya supaya roh orang yang diberikan beras itu kuat atau teguh. Saat penulis kembali bertanya bahwa batu juga keras, emas, pasir, mengapa bukan itu yang digunakan. Jawaban informan secara umum bahwa itu adalah sudah tradisi nenek moyang dan kita hanya mengikuti tradisi tersebut. Pendapat seluruh informan akan penulis rampung di simpulan tulisan ini.

\section{Konsepsi Batak Toba Mengenai Roh}

Dalam hubungan di antara jiwa dan roh, orang Batak Toba mengenal beberapa konsepsi, antara lain yang disebut "Tondi", "sahala" dan "begu". Dalam pengertian tentang Tondi, orang mempunyai asosiasi pikiran dengan roh. Namun dahulu orang Batak Toba membedakan kedua kata itu sesuai dengan fungsi dan sifatnya dalam kepercayaan.

Tondi atau roh adalah orang itu sendiri. Di dalam diri orang yang hidup terdapat Tondi. Apabila manusia sudah meninggal, maka sekaligus Tondinya lenyap. Tondi itu merupakan keadaan yang kekal bersama tubuh selama manusia hidup. Barangkali pengertian demikian sama betul dengan kepercayaan penganut agama Kristen yang mengatakan bahwa pada mula penciptaan, Allah telah menjadikan manusia dari debu tanah. Lalu ia menghembuskan nafas hidup ke dalam lobang hidungnya, lalu ia hidup menjadi roh yang hidup pula. Tetapi setelah manusia mati, roh itu terpisah dari tubuh, sedang tubuh itu sendiri kembali kepada 
tanah dari mana ia dijadikan dahulu. Dikatakan oleh Daud, “Apabila nyawanya melayang ia kembali ke tanah; pada hari itu juga lenyaplah maksud-maksudnya," Mazmur 146:4.

Banyak orang menyangka bahwa orang mati masih berkuasa. Orang-orang menyangka bahwa orang mati itu masih dapat berhubungan dengan orang hidup. Itulah sebabnya banyak orang, bahkan jutaan orang yang hidup di atas bumi ini memuja arwah nenek moyang. Menurut sangka mereka, roh-roh itu akan memberi rezeki, berkah kepada manusia, dan juga dapat mendatangkan kutuk. Untuk maksud itulah manusia menyampaikan sesajen kepada roh-roh tersebut.

Orang Batak Toba zaman dahulu menyakini bahwa Tondi sudah diterima setiap orang semasih dalam kandungan, demikian juga sahala yang menentukan diri orang itu kelak dalam masyarakat. Dalam buku Darah Batak Jiwa Protestan ditulis: Dunia yang didiami roh bagi orang Toba adalah ditentukan di sekitar perhatiannya yang khusus terhadap Tondinya sendiri yang dianggap sebagai pribadi; Tondi itu telah diterjemahkan dan berarti zat berjiwa. Uraian-uraian mengenai Tondi memberikan kepadanya sifat-sifat suatu benda yang berjasmani, walaupun tiada berbentuk seperti udara.
Tondi sebagai suatu keseluruhan berdiam dalam semua bagian badan, tetapi Tondi itu dan orang adalah integral (lengkap) satu sama lain dan bukanlah satuan-satuan yang terpisah. Hampir setiap benda alam dianggap mempunyai sejumlah Tondi yang hidup, yang dapat dijadikan pusat perhatian oleh keadaankeadaan yang khusus.

Tondi dianggap mempunyai suatu eksistensi yang berdiri sendiri dan kemapuan menggunakan pengaruhnya atas kejadian-kejadian yang sekarang dan yang akan datang. Tondi orang yang hidup, orang-orang yang meninggal dan mereka yang akan lahir adalah bersama dewata Tertinnggi di dunia atas dan bergabung dengan dia dengan cara yang sedemikian rupa hingga melalui Tondi itu Dewata Tertinggi sendiri berada dalam semua manusia dan mahkluk. Seluruh kehidupan agamaniah orang Batak yang mencari kesejahteraannya dalam dunia ini dan dunia yang akan datang dipenuhi dengan jalan merawat Tondinya menurut tingkahnya yang kadang-kadang berubahubah.

Tondi itu menentukan nasib setiap orang. Sebelum lahir Tondi setiap orang akan meminta sehelai daun pohon kehidupan dan di atas daun itu akan ditulis nasibnya. Jadi nasibnya bebas di berikan sesuai dengan yang dimintanya, demikian 
menurut keyakinan orang Batak zaman dahulu.

Tondi itu bukanlah diri yang lebih baik dalam orang atau malah bukan juga segi rohaniah pribadinya. Tondi itu ada dalam setiap aspek orang, termasuk rambut, kutu, keringat, air mati, kencing, tahi banyangan dan bahkan dalam namanamanya. Dan untuk membersihkan Tondi diadakanlah upacara, demikian ditulis dalam buku Darah Batak dan Jiwa Protestan.

Berkaitan dengan hal tersebut Tondi juga biasanya diartikan sebagai "roh". Orang Batak Toba memahami bahwa selain ada pada manusia, roh juga ada pada hewan. Fischer berpendapat bahwa perbedaan antara Tondi dengan sahala tetapi memiliki kedekatan. Tondi adalah semacam zat materiil yang dapat dibagibagi dan dialihkan tanpa penyusutan kuantitas pada diri orang yang mengeluarkannya. Sedangkan sahala menurutnya adalah atribut khusus dari Tondi. Menurut Vergouwen (2004), sahala sebagai daya khusus dari Tondi, yang bisa dilihat. Sahala seseorang adalah daya Tondi-nya sendiri dalam bentuk yang paling aktif dan paling mungkin dilihat.

Walaupun setiap orang memiliki Tondi tetapi hanya orang-orang tertentu saja yang memiliki sahala. Sahala dari Tondi seseorang dapat dilihat dari kemampuan, keberanian, kesaktian, kekuasaan, kekayaan serta banyaknya keturunan yang dimilikinya. Tondi orang yang sudah mati dipercayai mengalami evolusi menjadi begu (hantu). Begu orangorang penting akan berubah menjadi sumangot, kemudian akan menjadi sombaon (yang disembah). Tondi dari orang-orang penting yang menjadi sombaon dipercayai masih mempunyai hubungan langsung dengan keturunannya untuk memberkati dan menghukum kalau ada yang salah atau tidak disembah keturunannya. Karena itu, sahala sangat berkaitan dengan konsep kekuasaan bagi orang Batak Toba. Selain orang-orang penting dan sukses, sahala juga dipercayai dimiliki hula-hula. Hal ini menjadi salah satu faktor juga mengapa hula-hula sangat dihormati.

\section{Kekuatan Simbolik Beras dalam Ritus} Tahapan Kehidupan di Tanah Batak Setiap mahkluk hidup membutuhkan makanan dan minuman untuk mempertahankan kehidupannya. Beras memberi hidup dan menopang hidup manusia. Makanan utama ini menjadi lambang dari segala jenis makanan. Seorang yang kurus dapat menjadi gemuk dan sehat dengan makan nasi. Sebelum bekerja kita makan untuk beroleh kekuatan dan pekerjaan tak lain 
dari upaya untuk mempertahankan dan mengembangkan hidup. Bila seseorang memiliki banyak padi dilumbungnya, ia akan sanggup mewujudkan cita-citanya menggapai kebahagiaan dan kesempurnaan hidup. Bahkan kata Honda bagi negara Jepang memiliki arti sebagai ladang padi asli dan kata Toyota artinya ladang padi asli.

Sebagai penopang dan daya hidup suatu ritus beras atau makan menyertai manusia pada kesempatan-kesempatan hidup yang penting: kelahiran, pertunangan, seremoni inisiasi, perkawinan, tatkala beroleh cucu, perikatan perubahan status hidup dan pada upacara pemakaman. Dalam perkawinan pihak pemberi putri menyerahkan beras sebagai lambang kesuburan yang dihadirkan oleh putri mereka. Singkatnya beras menyangga dan mempertahankan hidup dalam manusia dan menyertainya dari lahir sampai mati. Sanggahan dan konversi serta mempertahankan hidup berada di luar control manusia. Sebagaimana hidup adalah sakral dan bersifat adikodrati, demikianlah konversi hidup lewat makanan berciri ilahi. Hakekatnya adalah numen dalam makanan.

Jika di perhatikan desa-desa asli Batak di sekitar danau Toba, semuanya merupakan desa lembah dengan ekologi persawahan. Terdapat hamparan sawah, sungai dan tali air (saluran irigasi tradisional) yang bermuara ke Danau Toba, dan perkampungan dengan pagar bambu hidup ditengahnya. Budidaya padi di sawah menjadi inti budaya orang Batak sejak awal. Orang Batak sangat terkenal dengan persawahan yang luas. Menanam padi bagi orang Batak adalah merupakan sebuah kewajiban, tentunya pernyataan ini saya terima dari nenek dan orangtua. Saya lahir dan tinggal dalam budaya Batak selama kurang lebih 23 tahun. Orangtua adalah seorang petani dan dalam pengamatan saya, tanaman padi harus selalu dibudayakan. Hampir setiap tahun padi wajib ditanam. Dengan menanam padi maka pertahanan bekal hidup sudah tersedia. Orang Batak akan merasa khawatir jika padi dalam tahun tertentu tidak ditanam. Untuk jelasnya orangtua saya mengatakan begini:

Molo nga pattik emei di balian nga adong be allangon, dang mabiar be iba haleon. (Kalau padi sudah ditanam di sawah sudah ada yang mau dimakan, tidak takut lagi jika tidak ada makanan)

Dalam buku Folklor Batak Toba penyataan di atas ada dicantumkan dan penulis berasumsi keduanya memiliki arti yang sama yaitu apabila kita menanam tanaman, tentu akan ada masa panen 
(Molo dung sinuan tontu adong ma panenon hasil ni nasinuani). Pernyataan yang demikian menyiaratkan bahwa pentingnya menanam padi untuk persediaan makanan. Persediaan padi di lumbung masing-masing rumah masyarakat Batak merupakan kebahagiaan bagi keluarga. Saat padi tidak tersedia lagi di rumah atau sudah habis maka keluarga itu akan sangat menderita dan merasa terkutuk. Perasaan itu akan timbul sendiri dan menyebabkan kekuatiran bagi keluarga. Budidaya menanam padi sudah menjadi budaya, sehingga beras yang menjadi nasi dan tepung sejak awal sudah menjadi bahasa simbolik dalam praktek budaya Batak. Beras adalah makanan pokok bagi masyarakat Batak dalam menggunakannya disertai dengan doa syukur dan harapan akan kebaikan.

Pemaparan di atas memberikan pemahamna mengenai hubungan beras denganroh atau Tondi. Dahulu maksud dari Boras Sipir ni Tondi adalah beras sebagai simbol untuk menguatkan roh, tetapi sekarang pengertian itu sudah mulai tidak dipergunakankan lagi. Tradisi Boras Sipir ni Tondi bisa dipergunakan dalam acara atau ritual tertentu, yaitu: Memasuki rumah baru, Acara adat pernikahan, Terjadinya suatu kejadian atau peristiwa marabahaya, Acara pembabtisan anak, dan naik jabatan.
Dalam peristiwa memasuki rumah baru, maka hula-hula dari pintu utama akan menaburkan beras ke segala penjuru rumah. Sambil menaburkan beras, hulahula lazimnya menyerukan doa berikut, "Mardangka ma baringin, di mual Pulo Batu; Horas Tondi madingin, pir Tondi matogu." Artinya: Berdahan pohon beringin, di telaga Pulo Batu; Selamat jiwa sejahtera, kuat jiwa teguh. Biasanya dilanjutkan dengan doa, "Tiur dalan bolusan, tio aek dapotan; Dapot ma na niluluan, jumpang ma na jinalahan". Artinya: Lapang jalan disusuri, jernih air ditemukan; Menemukan yang dicari, mencapai yang dicita.

Beras dalam adat pernikahan Batak Toba digunakan sebagai simbol kesuburan pasutri perempuan. Doa serupa juga disampaikan hula-hula pada pasangan pengantin saat upacara adat pernikahan. Tapi beras tidak ditabur bebas, melainkan tepat di atas kepala atau di ubun-ubun kedua pengantin. Maknanya sama, karena pengantin akan memasuki "hidup baru", secara fisik juga akan memasuki "rumah baru", maka pemberian boras si pir ni Tondi bermakna doa agar pasutri baru itu dalam hidupnya kelak meraih kekayaan, kesuksesan, kemuliaan (hamoraon, hagabeon, hasangapon ). Karena itu doanya disambung dengan ucapan, "Mamora ma hamu madingin, leleng ma 
hamu mangolu". Artinya: "Semoga kalian sejahtera, semoga kalian panjang umur". Singkatnya, "murah rejeki dan panjang umur".

Pada kasus seseorang atau sekeluarga lepas dari marabahaya, boras si pir ni Tondi juga ditaburkan di atas ubunubunnya. Makna simbolisnya adalah penguatan kembali roh atau jiwa mereka, agar dapat tegar menjalani hidup ke depan. Tidak terbelenggu oleh pengalaman buruk di masa lalu. Memang ada kalanya seseorang yang baru lepas marabahaya tampil sebagai orang linglung. Kata orang Batak, rohnya masih terpisah dari tubuhnya. Maka pemberian boras si pir ni Tondi diyakini dapat mengembalikan rohnya ke dalam tubuhnya. Sehingga dia akan tampil lagi sebagai orang yang lengkap jiwa-raganya.

Dalam acara pembatisan anak, biasanya dilakukan di rumah sendiri. Anak yang baru dibabtis tersebut digendong oleh orangtuanya dan orang-orang yang datang dalam acara akan memberkati dengan menaruh beras di atas kepala anak dan orangtuanya disertai dengan doa dan harapan supaya si anak sehat dan menajdi anak yang kuat. Kuat terhadap tantangan baik itu penyakit tubuh dan sosial.

\section{SIMPULAN}

Jawaban atas penelitian ini yaitu mengapa masyarakat Batak Toba menggunakan beras sebagai simbol penguat roh karena beras dimiliki oleh semua kalangan baik miskin dan yang kaya, ada nilai kesetaraan sosial didalamnya. Beras menjadi sumber makanan yang dapat memberikan kekenyangan bagi jasmani, ketika kebutuhan jasmani terpenuhi maka jiwa manusia akan tenang. Beras tidak berbahaya saat di taruh di atas kepala, tentunya ada unsur keselamatan. Saat memasuki rumah baru beras dihamburkan ke seluruh sudut rumah, tamu yang dikenai beras tidak akan merasa kesakitan. Ketiga unsur di atas menjadi hasil dari penelitian ini mengapa beras digunakan sebagai simbol penguat roh manusia. Yaitu beras menjadi alat kesetaraan sosial, beras menjadi kebutuhan jasmani, beras tidak menyakiti saat ditaruh dan dihamburkan. Ketiga unsur ini menjadi latar belakang mengapa beras digunakan sebagai simbol penguat roh.

Beras menjadi kekuatan simbolik dalam ritus tahapan kehidupan masyarakat Batak Toba karena memiliki sejarah dan kegunaan beras yang sangat banyak. Selain menjadi makanan pokok beras digunakan sebagai simbol penguat roh atau jiwa dalam tradisi pemberian 
Boras Si Pir Ni Tondi. Saat kelahiran beras digunakan sebagai simbol penguat roh anak, dalam keadaan marahbahaya beras digunakan sebagai simbol penguat roh, saat naik pangkat beras di gunakan sebagai simbol penguat roh, saat kematian beras juga di gunakan sebagai simbol penguat roh. Mulai dari ritus kelahiran sampai dengan ritus kematian masyarakat Batak Toba selalu menggunakan beras sebagai simbol penguat roh. Masyarakat Batak meyakini bahwa semua benda memiliki Tondi, khususnya padi mulai dari menanam sampai dengan memanen melakukan ritus. Padi sangat dihargai karena memiliki proses yang panjang untuk sampai di panen.

\section{DAFTAR PUSTAKA}

Anan, T. (2015). Benda-Benda Bertuah Masyarakat Jawa. Yogyakarta: NARASI

Gaol, N.L.L. (2007 ) penelitiannya yang berjudul "Tanda-tanda Dalam Perkawinan Batak Toba (Tinjauan Semiotika)". Medan: USU.

Hasugian, M.R. (2017). Upacara Kematian Saur Matua Batak Toba, Lingua, Center of Language of Culture Sudies, 14(2): 235

Misrita. (2010). Makna Metaforik Behas 'Beras' Dalam Tradisi Tandak Tawur Suku Dayak Ngaju Di Kalimantan Tengah, Diunduh di https://www.academia.edu/14860181/MA KNA METAFORIK BEHAS BERAS DALAM T RADISI TANDAK TAWUR SUKU DAYAK NG AJU DI KALIMANTAN TENGAH 1 tanggal 2 Juli.

Moleong, L.J. (1989). Metode Penelitian Kualitatif. Bandung: Remaja Karya.

Nasir, M. (1988). Metode penelitian Kualitatif. Jakarta: Ghalia Indonesia.
Sameng, M.W., Munawaroh, R. \& Suprapto. (2003) "Formulasi Sediaan Sabun Padat Sari Beras (Oryza Sativa) Sebagai Anti Bakteri Terhadap Staphylococcus Epidermidis. Universitas Muhammadyah Surakarta. Diunduh di http://scholar.googleusercontent.com/schol ar? $\mathrm{q}=$ cache:0NMyDzrF4uol:scholar.google.co $\underline{\mathrm{m} / \text { \&hl=en\&as } \mathrm{sdt}=0,5}$ tanggal 30 Juni.

Simatupang, D.E. (2008). Upacara Saur Matua: Konsep "Kematian Ideal" pada Masyarakat Batak Toba, Balai Arkeologi Medan, 11 (21): 24.

Simatupang, L.L. (2015) penelitian yang berjudul "Pengalaman Pasien Suku Batak Toba Dengan Gagal Ginjal Kronis Dalam Menjalani Hemodialisa". Idea Nursing Journa, VI(3): 1926.

Sitohang, A. (2016). "Falsafah " Boras Sipir Ni Tondi" Dalam Upacara Pesta Adat Perkawinan Batak Toba Di Desa Pusuk I Kecamatan Parlilitan Kabupaten Humbang Hasundutan". Skripsi. Program Studi Pendidikan Antropologi Fakultas Ilmu Sosial Universitas Negeri Medan

Sugiyono. (2013). Metode Penelitian Kuantitatif, Kualitatif dan R\&D. Bandung: Alfabeta.

Suharyanto, A. (2012). Makna Gondang dan Torttor dalam Upacara Ritual Parmalim Nasiak Bagi di Hutatinggi Laguboti Toba Samosir, dalam Apresiasi Simbol dalam Seni Nusantara 1, 59-73, Bandung: CV. WarliArtika

Suharyanto, A. (2019). Makna Ritual Marari Sabtu Pada Ruas Ugamo Malim, JISA (JURNAL ILMIAH SOSIOLOGI AGAMA) 2 (1), 14-28

Suharyanto, A., (2016), Pusat Aktivitas Ritual Kepercayaan Parmalim di Huta Tinggi Laguboti, JPPUMA: Jurnal Ilmu Pemerintahan dan Sosial Politik UMA (Journal of Governance and Political UMA), 4 (2): 182195.

Tambunan, E.H. (1982) Sekelumit Mengenai Masyarakat Batak Toba Dan Kebudayaannya Sebagai Sarana Pembangunan, Bandung: TARSITO

Vergouwen, J. (2004). Masyarakat dan Hukum Adat Batak Toba" Yogyakarta: LkiS

Wiflihani \& Suharyanto, A (2011). Upacara Sipaha Sada Pada Agama Parmalim Di Masyarakat Batak Toba Dalam Kajian Semiotika, JUPIIS: Jurnal Pendidikan Ilmu-ilmu Sosial, 3(1): $103-112$ 